\title{
Upaya peningkatan kompetensi guru dalam menyusun silabus dan rencana pelaksanaan pembelajaran melalui supervisi akademik yang berkelanjutan
}

\author{
Risna Hertati*) \\ Sekolah Dasar Negeri 27 Pasar Kambang
}

\begin{tabular}{l} 
Article Info \\
\hline Article history: \\
Received April $19^{\text {th }}, 2021$ \\
Revised May $18^{\text {th }}, 2021$ \\
Accepted Jun $19^{\text {th }}, 2021$ \\
\hline
\end{tabular}

\section{Keyword:}

Kompetensi Guru

RPP

KKG

\begin{abstract}
Setiap proses pasti selalu meliputi tiga kegaiatan utama yakni perencanaan, pelaksanaan dan evaluasi. Demikian pula yang terjadi dengan proses belajar mengajar di sekolah. Seorang guru diharuskan melakukan perencanaan, pelaksanaan dan evaluasi pembelajaran. Untuk mengecek originalitas silabus dan RPP yang disusun guru, kepala sekolah melakukan supervise kelas. Hal ini dilakukan untuk menyesuaikan rencana yang dimuat dalam silabus dan RPP dengan penerapannya di kelas. Jika sesuai maka dapat dipastikan, kompetensi guru dalam menyusun silabus dan RPP tersebut benar (bukan jiplakan atau dibuatkan orang lain). Jika banyak ketidaksesuaian maka ada kemungkinan silabus. Supervisi akademik secara berkelanjutan terbukti secara ilmiah dapat meningkatkan kompetensi guru dalam menyusun silabus dan RPP di di UPT SDN 27 Pasar Kambang Kec. Lengayang. Ini terbukti dengan meningkatnya jumlah silabus guru yang baik dari $85 \%$ menjadi $100 \%$ setelah supervise akademik. Selain itu jumlah RPP yang berkualitas baik juga meningkat dari $85 \%$ menjadi $100 \%$.
\end{abstract}

\section{Corresponding Author:}

Risna Hertati

Sekolah Dasar Negeri 27 Pasar Kambang

Email: risnahertati@gmail.com

\section{Pendahuluan}

Pendidikan adalah proses merubah manusia menjadi lebih baik, lebih mahir dan lebih terampil. Untuk mencapai tujuan tersebut tentunya dibutuhkan strategi yang disebut dengan strategi pembelajaran. Dalam strategi pembelajaran terkandung tiga hal pokok yakni perencanaan, pelaksanaan dan evaluasi. Perencanaan program berfungsi untuk memberikan arah pelaksanaan pembelajaran sehingga menjadi terarah dan efisien. Salah satu bagian dari perencanaan pembelajaran yang sangat penting dibuat oleh guru sebagai pengarah pembelajaran adalah silabus dan Rencana Pelaksanaan Pembelajaran (RPP).

Silabus memberikan arah tentang apa saja yang harus dicapai guna menggapai tujuan pembelajaran dan cara seperti apa yang akan digunakan. Selain itu silabus juga memuat teknik penilaian seperti apa untuk menguji sejauh mana keberhasilan pembelajaran. Rencana Pelaksanaan Pembelajaran (RPP) adalah instrument perencanaan yang lebih spesifik dari silabus. Rencana Pelaksanaan Pembelajaran ini dibuat untuk memandu guru dalam mengajar agar tidak melebar jauh dari tujuan pembelajaran.

Dengan melihat pentingnya penyusunan perencanaan pembelajaran ini, guru semestinya tidak mengajar tanpa adanya rencana. Namun sayang perencanaan pembelajaran yang mestinya dapat diukur oleh kepala 
sekolah ini, tidak dapat diukur oleh kepala sekolah karena hanya direncanakan dalam pikiran sang guru saja. Akibatnya kepala sekolah sebagai pembuat kebijakan di sekolah tidak dapat mengevaluasi kinerja guru secara akademik. Kinerja yang dapat dilihat oleh kepala sekolah hanyalah kehadiran tatap muka, tanpa mengetahui apakah kemampuan guru dalam mengelola pembelajaran sudah sesuai dengan harapan atau belum, atau sudahkah kompetensi dasar yang harus dikuasai oleh siswa terkuasai dengan benar.

Hasil pengamatan di UPT SDN 27 Pasar Kambang Kec. Lengayang didapatkan data sebagai berikut: 1) Hanya $60 \%$ guru yang menyusun silabus dan RPP; 2) Secara kualitas, silabus dan RPP yang baik baru mencapai angka $30 \%$ dari silabus dan RPP yang dibuat oleh guru.

Untuk mengatasi permasalahan tersebut, peneliti yang berkedudukan sebagai kepala sekolah di atas merencanakan untuk melakukan supervise akademik yang berkelanjutan. Dengan metode tersebut diharapkan setelah kegiatan, guru yang menyusun silabus dan RPP meningkat menjadi 90\% dan kualitas silabus dan RPP yang baik menjadi $80 \%$.

Berdasarkan uraian di atas, maka penulis selaku kepala sekolah tertarik untuk mengadakan Penelitian Tindakan Sekolah yang berjudul: "Upaya peningkatan kompetensi guru dalam menyusun silabus dan RPP melalui supervisi akademik yang berkelanjutan di UPT SDN 27 Pasar Kambang Kec. Lengayang”

\section{Metode}

Lokasi penelitian adalah di UPT SDN 27 Pasar Kambang Kec. Lengayang. Waktu pelaksanaan direncanakan selama 2 bulan yaitu bulan September 2020 sampai Oktober 2020 pada semester I Tahun Pelajaran 2020/2021. Penelitian ini dilaksanakan sendiri oleh Peneliti di UPT SDN 27 Pasar Kambang Kec. Lengayang dan yang menjadi subjek dalam penelitian ini adalah guru di UPT SDN 27 Pasar Kambang Kec. Lengayang yang berjumlah 21 orang guru. Teknik pengumpulan data dalam penelitian ini diperoleh melalui observasi dan catatan data lapangan, wawancara, hasil tes dan catatan hasil refleksi/diskusi yang dilakukan oleh peneliti dan mitra peneliti. Penentuan teknik tersebut didasarkan ketersediaan sarana dan prasana dan kemampuan yang dimiliki peneliti dan mitra peneliti.

Dalam penelitian tindakan kelas ini, teknik analisis data yang digunakan adalah teknik deskriptif. Data yang dianalisis berupa rata-rata dan prosentase hasil pngamatan dan observasi terhadap guru. Data yang diperoleh disajikan dalam bentuk tabel.

Penelitian ini dilakukan dengan metode penelitian tindakan kelas yang berlangsung selama 2 siklus. Masing-masing siklus terdiri dari tahapan perencanaan, pelaksanaan, observasi dan refleksi. Metode penelitian yang dilakukan peneliti adalah dengan melaksanakan supervisi akademik yang meliputi supervise tradisional dan supervise klinis. Pelaksanaan dari perencanaan tindakan dilakukan melalui tahapan-tahapan yaitu sebagai berikut:

1. Tahap perencanaan Awal

Langkah awal yang direncanakan pada penilitian tindakan sekolah ini terdiri dari beberapa kegiatan, yakni:

a. Identifikasi masalah. Pengidentifikasian masalah dilakukan oleh peneliti dengan menggunakan data penyerahan perangkat pembelajaran tahun pelajaran 2020/2021. Ini dilakukan pada bulan Agustus 20120.

b. Penyusunan proposal. Penyusunan proposal dilaksanakan oleh peneliti pada tanggal 1 September 2020 dengan judul "Upaya Peningkatan Kompetensi Guru Dalam Menyusun Silabus dan RPP Melalui Supervisi Akademik Yang Berkelanjutan di UPT SDN 27 Pasar Kambang Kec. Lengayang".

c. Mempersiapkan instrument. Pada tahap ini, peneliti menyiapkan seluruh instrument penelitian berupa lembar pengamatan supervise yang terdiri dari data jumlah guru yang membuat silabus dan RPP dan data kualitas silabus dan RPP yang dibuat oleh guru.

2. Siklus pertama.

a. Perencanaan. Tahap perencanaan pelaksanaan siklus 1 dilaksanakan peneliti pada minggu pertama September 2020.

b. Pelaksanaan. Pelaksanaan tindakan pada siklus pertama dilaksanakan pada minggu ke-2 Oktober 2020.

c. Observasi. Pada tahap ini peneliti melakukan kegiatan observasi terhadap seluruh kejadian yang terjadi selama tahap pelaksanaan tindakan siklus 1 . Selain itu peneliti juga mengidentifikasi masalah-masalah lanjutan yang timbul dari pelaksanaan tindakan di siklus 1 . 
d. Refleksi. Pada tahap refleksi, peneliti melakukan evaluasi terhadap tindakan dan data-data yang diperoleh. Kemudian dilanjutkan dengan pertemuan bersama kolaborator untuk membahas hasil evaluasi dan penyusunan langkah-langkah untuk siklus kedua.

\section{Siklus II}

a. Perencanaan. Tahap perencanaan pada siklus kedua ini, peneliti melakukan pertemuan dengan kolaborator untuk menyusun penjadwalan supervise kelas dan menyiapkan instrument supervise untuk siklus kedua.

b. Pelaksanaan. Pada tahap ini, guru-guru yang sudah siap perangkat perencanaan pembelajarannya disupervisi kelas oleh peneliti. Hal ini untuk melihat kesesuaian perencanaan pembelajaran dengan pelaksanaan pembelajaran.

c. Observasi. Di tahap observasi siklus kedua, peneliti mengobservasi kesesuaian perencanaan pembelajaran dengan pelaksanaan pembelajaran serta melihat keberterimaan siswa dalam proses belajar mengajar. Pada tahap ini pula, peneliti mengumpulkan data-data yang terjadi selama tahap pelaksanaan.

d. Refleksi. Pada tahap refleksi siklus kedua, peneliti melakukan evaluasi bersama guru yang disupervisi terhadap hasil observasi di siklus kedua

\section{Hasil dan Pembahasan}

\section{Hasil Penelitian}

\section{Pra Siklus}

1. Kuantitas silabus dan RPP tahun pelajaran $2020 / 2021$

Pada akhir tahun pelajaran 2020/2021, peneliti mencatat guru yang menyetorkan perangkat pembelajaran untuk ditandatangani. Terlihat bahwa data dasar guru yang meyusun perangkat pembelajaran adalah sebesar 60 dan 63\%. Dari silabus dan RPP yang terkumpul ini, kemudian penulis melakukan penelaahan terhadap kualitas dari perangkat pembelajaran yang dikumpulkan terutama pada silabus dan RPP. Data yang diperoleh dari penelaahan tersebut dapat digambarkan pada table kualitas silabus dan RPP di UPT SDN 27 Pasar Kambang Kec. Lengayang pada sub berikut.

2. Kualitas silabus dan RPP guru tahun pelajaran $2020 / 2021$

Kualitas silabus dan RPP yang dibuat oleh guru di UPT SDN 27 Pasar Kambang Kec. Lengayang secara umum dapat dikatakan kurang baik. Hal ini dikarenakan masih banyak silabus dan RPP yang masih menggunakan format lama dan terkesan tidak original (copy paste dari orang lain). Hal ini terlihat dari tidak timbulnya visi dan misi serta tujuan sekolah pada silabus dan RPP yang dibuat oleh guru.

Bahwa kualitas silabus da RPP guru UPT SDN 27 Pasar Kambang Kec. Lengayang pada tahun pelajaran 2020/2021 masih sangat rendah. Dari 13 orang guru yang silabus dan RPP-nya dianalisa oleh peneliti, hanya rata-rata 31\% guru yang memiliki silabus dan RPP yang sesuai dan dinilai baik. Lebih rinci, prosentase guru yang silabusnya baik (di atas 70) adalah 23\% dan guru yang RPPnya baik (di atas 70 ) adalah $38 \%$.

\section{Siklus I}

1. Kuantitas guru yang menyusun silabus dan RPP setelah siklus I

Pada rapat awal tahun pelajaran 2020/2021, peneliti memerintahkan kepada seluruh guru untuk membuat perangkat pembelajaran. Setelah berjalan selama hampir tiga bulan, peneliti mengumumkan kepada seluruh guru bahwa pada bulan September 2020 akan dilakukan supervise terhadap administrasi guru.

Pada siklus ini seluruh guru diminta untuk mengumpulkan perangkat pembelajaran tersebut. Selanjutnya peneliti melakukan analisis dan penilaian terhadap kuantitas guru yang menyetorkan perangkat pembelajaran terutama silabus dan RPP. Dari hasil perhitungan peneliti terhadap jumlah guru yang mengumpulkan silabus dan RPP didapatkan data jumlah guru yang mengumpulkan silabus dan RPP pada awal siklus 1, dapat terlihat bahwa dengan informasi adanya supervise akademik terhadap guru dapat meningkatkan kuantitas jumlah guru yang menyusun silabus dan RPP yang sebelumnya hanya 63\%, mengalami peningkatan kuantitas menjadi $85 \%$. Dari data tersebut juga dapat dilihat adanya guru yang hanya menyerahkan silabus tanpa dengan RPP-nya serta ada yang belum menyetorkan silabus dan RPP

2. Kualitas silabus dan RPP setelah siklus ke-1

Sebelum melakukan supervise individual terhadap seluruh guru terutama kepada guru yang belum menyetorkan silabus dan RPP. Peneliti melakukan analisa kedua terhadap sampel silabus dan RPP yang 
dibuat oleh guru. Hasil analisa revisi silabus dan RPP memperlihatkan terjadinya peningkatan kualitas silabus dan RPP. Dimana kualitas A dan B meningkat dari 33\% menjadi 85\%.

\section{Siklus II}

1. Kuantitas guru yang menyusun silabus dan RPP setelah siklus II

Pada rapat awal tahun pelajaran 2020/2021, peneliti memerintahkan kepada seluruh guru untuk membuat perangkat pembelajaran. Setelah berjalan selama hampir tiga bulan, peneliti mengumumkan kepada seluruh guru bahwa pada bulan oktober 2020 akan dilakukan supervise terhadap administrasi guru.

Pada siklus ini seluruh guru diminta untuk mengumpulkan perangkat pembelajaran tersebut. Selanjutnya peneliti melakukan analisis dan penilaian terhadap kuantitas guru yang menyetorkan perangkat pembelajaran terutama silabus dan RPP. Dari hasil perhitungan peneliti terhadap jumlah guru yang mengumpulkan silabus dan RPP didapatkan data guru yang mengumpulkan silabus dan RPP pada awal siklus 1, dapat terlihat bahwa dengan informasi adanya supervise akademik terhadap guru dapat meningkatkan kuantitas jumlah guru yang menyusun silabus dan RPP yang sebelumnya hanya $85 \%$, mengalami peningkatan kuantitas menjadi $100 \%$. Dari data tersebut juga dapat dilihat adanya guru yang hanya menyerahkan silabus tanpa dengan RPP-nya serta ada yang belum menyetorkan silabus dan RPP

\section{Kualitas silabus dan RPP setelah siklus II}

Sebelum melakukan supervise individual terhadap seluruh guru terutama kepada guru yang belum menyetorkan silabus dan RPP. Peneliti melakukan analisa kedua terhadap sampel silabus dan RPP yang dibuat oleh guru. Hasil analisa revisi silabus dan RPP pada table diatas memperlihatkan terjadinya peningkatan kualitas silabus dan RPP. Dimana kualitas A dan B meningkat dari 85\% menjadi 100\%.

Pada siklus kedua ini, penelitian dilanjutkan dengan menganalisa/menguji keaslian silabus dan RPP yang disusun oleh guru. Metode yang digunakan adalah dengan melakukan supervise kelas. Dari pelaksanaan rencana pembelajaran ini, dapat terlihat keaslian penyusunannya. Hasil dari analisa penguat tersebut, menunjukkan bahwa silabus dan RPP yang dikumpulkan benar disusun oleh guru yang bersangkutan. Karena terjadi kesesuaian scenario antara perencanaan dan pelaksanaan di kelas. Dari hasil analisis di atas, maka dapat ditarik sebuah kesimpulan bahwa silabus dan RPP yang dikumpulkan guru adalah bersifat original. Hal ini terlihat dengan semua guru mampu melaksanakan pembelajaran sesuai dengan rencana yang dibuat.

\section{Pembahasan \\ Siklus I}

Pada awalnya kualitas silabus dan RPP guru UPT SDN 27 Pasar Kambang Kec. Lengayang pada tahun pelajaran 2020/2021 masih sangat rendah. Dari 13 orang guru yang silabus dan RPP-nya dianalisa oleh peneliti, hanya rata-rata $63 \%$ guru yang memiliki silabus dan RPP yang sesuai dan dinilai baik.

Dari data jumlah guru yang mengumpulkan silabus dan RPP pada awal siklus 1, dapat terlihat bahwa dengan informasi adanya supervise akademik terhadap guru dapat meningkatkan kuantitas jumlah guru yang menyusun silabus dan RPP yang sebelumnya hanya 63\%, mengalami peningkatan kuantitas menjadi $85 \%$. Dari data tersebut juga dapat dilihat adanya guru yang hanya menyerahkan silabus tanpa dengan RPP-nya serta ada yang belum menyetorkan silabus dan RPP

\section{Siklus II}

Dari data jumlah guru yang mengumpulkan silabus dan RPP pada awal siklus I, dapat terlihat bahwa dengan informasi adanya supervise akademik terhadap guru dapat meningkatkan kuantitas jumlah guru yang menyusun silabus dan RPP yang sebelumnya hanya $85 \%$, mengalami peningkatan kuantitas menjadi $100 \%$. Dari data tersebut juga dapat dilihat adanya guru yang hanya menyerahkan silabus tanpa dengan RPP-nya serta ada yang belum menyetorkan silabus dan RPP Hasil analisa revisi silabus dan RPP pada table diatas memperlihatkan terjadinya peningkatan kualitas silabus dan RPP. Dimana kualitas A dan B meningkat dari $85 \%$ menjadi $100 \%$.

Pada siklus kedua ini, penelitian dilanjutkan dengan menganalisa/menguji keaslian silabus dan RPP yang disusun oleh guru. Metode yang digunakan adalah dengan melakukan supervise kelas. Dari pelaksanaan rencana pembelajaran ini, dapat terlihat keaslian penyusunannya. 


\section{Simpulan}

Berdasarkan hasil penelitian yang terurai pada BAB IV, kami dapat menyimpulkan bahwa:

1. Supervisi akademik secara berkelanjutan terbukti secara ilmiah dapat meningkatkan kompetensi guru dalam menyusun silabus dan RPP di di UPT SDN 27 Pasar Kambang Kec. Lengayang. Ini terbukti dengan meningkatnya jumlah silabus guru yang baik dari $85 \%$ menjadi $100 \%$ setelah supervise akademik. Selain itu jumlah RPP yang berkualitas baik juga meningkat dari $85 \%$ menjadi $100 \%$.

2. Langkah-langkah yang mengakibatkan terjadinya peningkatan kompetensi guru dalam menyusun silabus dan RPP tersebut meliputi langkah-langkah sebagai berikut: (1) Pengumuman rencana supervisi terhadap guru. (2) Pelaksanaan supervise individual, dimana setiap guru diminta mempresentasikan silabus dan RPP-nya kepada kepala sekolah, kemudian kepala sekolah memberikan masukan terhadap kekurangan silabus dan RPP guru. (3) Untuk mengecek originalitas silabus dan RPP yang disusun guru, kepala sekolah melakukan supervise kelas. Hal ini dilakukan untuk menyesuaikan rencana yang dimuat dalam silabus dan RPP dengan penerapannya di kelas. Jika sesuai maka dapat dipastikan, kompetensi guru dalam menyusun silabus dan RPP tersebut benar (bukan jiplakan atau dibuatkan orang lain). Jika banyak ketidaksesuaian maka ada kemungkinan silabus dan RPP tersebut dibuatkan oleh orang lain.

3. Peningkatan kompetensi guru dalam menyusun silabus dan RPP yang baik meningkat sebesar $58 \%$ dan $85 \%$.

\section{Referensi}

Anwar, Moch. Idochi. (2004). Administrasi Pendidikan dan Manajemen Biaya Pendidikan. Bandung: Alfabeta Depdiknas. (1997). Petunjuk Pengelolaan Adminstrasi Sekolah Dasar. Jakarta: Depdiknas.

Depdiknas. (2001). Manajemen Peningkatan Mutu Berbasis Sekolah. Jakarta: Depdiknas.

Depdiknas. (2010). Supervisi Akademik; Materi Pelatihan Penguatan Kemampuan Kepala Sekolah; Jakarta: Depdiknas.

Harahap, Baharuddin. (1983). Supervisi Pendidikan yang Dilaksanakan oleh Guru, Kepala Sekolah, Penilik dan Pengawas Sekolah. Jakarta: Damai Jaya

Majid, Abdul. (2005). Perencanaan Pembelajaran: Mengembangkan Standar Kompetensi Guru. Bandung: PT Remaja Rosdakarya.

Muhaimin (2004). Paradigma Pendidikan Islam. Bandung: PT Remaja Rosdakarya.

Mulyasa, E., (2003). Kurikulum Berbasis Kompetensi: Konsep, Karakteristik, dan Implementasi. Bandung: PT Remaja Rosdakarya

Sahertian, Piet A. (2000). Konsep-Konsep dan Teknik Supervisi Pendidikan Dalam Rangka Pengembangan Sumber Daya Manusia. Jakarta: Rineka Cipta.

Sapari, Achmad. (2002). Pemahaman Guru Terhadap Inovasi Pendidikan. Artikel. Jakarta: Kompas (16 Agustus (2002).

Supandi. (1996). Administrasi dan Supervisi Pendidikan. Jakarta: Departemen Agama Universitas Terbuka.

Suprihatin, MD. (1989). Administrasi Pendidikan, Fungsi dan Tanggung Jawab Kepala Sekolah sebagai Administrator dan Supervisor Sekolah. Semarang: IKIP Semarang Press.

Surya, Muhammad. ( 2003). Psikologi Pembelajaran dan Pengajaran. Bandung: Yayasan Bhakti Winaya

Suryasubrata. (1997). Proses Belajar Mengajar di Sekolah. Jakarta: Rineka Cipta.

Usman, Moh. Uzer. (1994). Menjadi Guru Profesional. Bandung: PT Remaja Rosdakarya.

Wahidin. (2008). 13 Faktor untuk menjadi Kepala Sekolah Yang Efektif. 